\title{
PRE-MARITAL AND EX-NUPTIAL FERTILITY (ILLEGITIMACY) IN CANADA, 1921-1972
}

\author{
Raghubar D. Sharma \\ The University of Manitoba, Winnipeg, Manitoba, Canada
}

Résumé - Dans cette étude on a examiné les tendances dans l'illégitimité canadienne en se fondant sur les nombres absolus des naissances illégitimes, le rapport de l'illégitimité et les taux des naissances illégitimes de 1921 à 1972. Il y a une tendance montante en illégitimité de 1921 à 1970. Le taux commenca à baisser aprés 1970. Ce d'habitude attribuable à la prédominance des avortements thérapeutiques aprés le changement en 1969 de la loi canadienne sur l'avortement, bien que notre récente analyse montre que la détermination de l'effet du changement de la loi sur l'avortement sur l'illégitimité exgigera une étude à long terme. Des comparaisons internationales montrent que les taux canadiens sont plus élevés que ceux de la population blanche des Etats-Unis, bien qu'ils soient plus bas que ceux de l'ensemble des taux américains. Le taux de fécondité illégitime dépasse le taux canadien, mais il est remarquablement différent comme on l'aurait supposé. Les taux australiens étaient presque le double des taux canadiens en 1921, mais les taux canadiens des naissances illégitimes s'approchèrent très près des taux australiens dans les derniéres années.

Abstract - Trends in Canadian illegitimacy have been examined on the basis of absolute numbers of illegitimate births, illegitimacy ratio, and illegitimate birth rates from 1921 to 1972. An upward trend in illegitimacy was observed from 1921 to 1970 , which was reversed after 1970 . This decline is usually attributed to the prevalence of therapeutic abortion following changes to Canadian abortion laws in 1969. This analysis, however, shows that a long-term study of abortion law changes is necessary to determine their true effect on illegitimacy. International comparisons show that Canadian rates are higher than that for the white population of the U.S.A., though they are lower than the overall American rates. The American illegitimate fertility rate exceeds the Canadian, but is markedly different, as would be conjectured. In 1921, Canadian illegitimate birth rates were approximately half those of Australia. This disparity was lessened with time and eventually the rates became almost equal.

Key Words - Canadian illegitimacy, illegitimate birth rates, trends, illegitimacy ratio

\section{Introduction}

Illegitimacy is not a recent phenomenon. It has been known to exist at various times in various societies. Laslett and Oosterveen (1973) studied illegitimacy in England, covering the period from 1561 to 1960 , and noted an interesting rhythmic rise and fall over two hundred years. Cutright and Galle (1973) estimated that in 1920 there were 86,000 illegitimate births in the United States. Basavarajappa (1968) noted that during the $1960 \mathrm{~s}$, the rate of pre-marital pregnancies in Australia was the same as that in England and Wales, and the United States, but lower than in Denmark.

Span (1912) says illegitimate children are born with as good chance of bodily and cultural development as legitimate children. According to Kammerer (1968), public attitude toward the question of sex in general, and illegitimacy in particular, needs revision. Vincent (1969) revealed that unwed mothers are the largest single source of adoptable infants for the estimated three million involuntarily childless couples in the U.S.A.

It has been documented that most illegitimate children are not wanted; therefore, the logical beginning to prevent at least some of these births is the expansion of family planning services, so as to make them available to all sections of the population (Berkov, 1968; Cutright, 1973; The State of 
California Public Health Report, 1967). Cutright (1972) suggested that future decline in illegitimacy could be achieved by expanding contraceptive programs and making abortion available on demand.

The basic measures used to study illegitimacy are illegitimacy ratio (illegitimate births per 100 live births) and age-specific birth rates. Goode (1966) compared the illegitimacy levels of several countries by using the illegitimacy ratio, and showed that the United States in 1963 and England and Wales in 1962 were at about the same level (63 and 66 illegitimate births per 1,000 live births, respectively). Kumar (1969) contended that the situation is more complex and that the illegitimacy ratio does not measure the "level of illegitimacy," as does the illegitimate rate. He showed that measurements based on illegitimacy rates differed considerably in two countries. The present study has been conducted primarily on the basis of age in specific illegitimate birth rates, though illegitimacy ratios have also been discussed.

\section{Data and Method}

In the present study, in order to calculate age-specific rates, the number of illegitimate births were related to the number of unmarried women (never-married, widowed, and divorced). 'The figures for illegitimate births by age of mother were collected from the yearly vital statistics reports of Statistics Canada. According to these reports, "illegitimacy does not refer to the births conceived out of wedlock, but to those in which the parents reported themselves as not having been married to each other at the time of birth or registration and, in the case of Ontario, since 1949, to those births in which the marital status of the mother was reported as single." In the present study, illegitimate births are exclusive of stillbirths.

Age-specific illegitimate birth rates ${ }^{2}$ were calculated, using the 15-19 years age group as an example, by the following formula:

$$
\text { The illegitimate birth rate }(15-19)=\frac{\beta_{u}^{15-19}}{P f}
$$

where, $\beta_{u}^{15-19}$ represents births to unmarried women between 15 and 19 years of age and

$P^{15-19}$ represents unmarried women in 15-19 years age group.

The number of children born to women under 15 was incorporated in the age group 15-19, and those born to women over 49 were added to the 45-49 years age group; those born to women with age not stated were prorated into various age groups by the following formula:

$$
R=\frac{\text { Total births in year } X}{\text { Total births in year } X-\text { births with }}
$$

The births in every age group were multiplied by $R$ to obtain adjusted numbers.

\section{Results}

In this section, trends in illegitimacy will be discussed in two parts: at the interval of census year and in the post-war years. Post-war years have a great significance in demographic trends, and special attention will therefore be devoted to these years.

\section{Trends in Numbers of Illegitimate Births}

In 1921, the total number of illegitimate births in Canada, excluding Newfoundland, Quebec, the Northwest Territories and the Yukon, was estimated at 3,334. In 1931, 8,365 illegitimate births were 
registered in Canada. By 1941, this figure had risen to 10,101 ; by 1951 , to 14,537 ; by 1956 , to 17,510 ; and by 1961 , to 21,490 . In $1966,29,391$ illegitimate births were registered - a statistic which increased to 35,588 by 1970 . This increase was in part due to a rise in the population of unmarried women, which will become clear when age-specific illegitimate birth rates are discussed. The available data reveals that the number of illegitimate births started declining after 1970: in 1971, the number dropped to 32,693 ; by 1972 , to 31,257 . In fact, this decline continued: according to Statistics Canada, the number of illegitimate births was 31,005 in 1973 , and 29,183 in 1974. After looking at age-specific illegitimate birth rates, we shall try to explore the reasons for this decline.

\section{Trends in Illegitimacy Ratio in Canada from 1921 to 1972}

The illegitimacy ratio shows a rising trend (Table 1). From 1941 to 1958, the change was negligible, except for the years 1944 and 1945 - most probably, this was due the fact that many couples were separated at the end of World War II. By 1970, the illegitimacy ratio rose to 9.6. This is the highest value reached in data available so far. After 1970, the ratio started to decline, so that for 1971 and 1972 it was 9.0. In 1969, the government of Canada legalized therapeutic abortion under certain circumstances, and the observed drop in illegitimacy is usually attributed to this change. However, our recent analysis indicates that the impact of the change in the abortion law on illegitimacy is not yet clear and will require long term study (Sharma, 1976).

\section{Trends in Age-Specific Illegitimate Fertility Rates in Canada from 1921 to 1971 (Census Years)}

The illegitimacy ratio is frequently used as a measure of the level of illegitimacy, but it is not as good a measure as age-specific illegitimate fertility rates. The illegitimacy ratio is heavily influenced by marital status. The denominator in the illegitimacy ratio is the total number of live births given by both married and unmarried mothers. If, in a population, the number of married women is higher, the number of children born to married women will also be higher, and consequently the illegitimacy ratio will be deflated; the reverse will be true if the proportion of married women in the population is lower. Henripin (1972) also suggested that if the population of married women increases, particularly under the age of 30, a reduction in illegitimate births can be expected unless the fertility of married women increases proportionately. Illegitimate births are far more subject to the influence of underregistration than are legitimate births. Moreover, age-specific illegitimate fertility rates are not influenced by the age structure of mothers because illegitimate births are related to the group of unmarried women, to which the mother belongs. For these reasons, and for analytical purposes, both measures deserve to be shown.

Table 2 shows illegitimate birth rates by age of mother for each census year from 1921 to 1971 . Table 3 reveals the percentage change in the age-specific illegitimate birth rate for women aged 15-49, from one year to another. Trends from 1946 to 1972 will be discussed in the next section.

It can be observed from Table 2 that there is an upward trend for almost all age groups to 1966 . In 1971 , illegitimate birth rates declined for all age groups except the teenage (15-19) group. In 1941, the illegitimate birth rate rose in that same group, while in all other age groups there was a slight decline. It is interesting to note that the rise in the 15-19 years group contributed to a 3.9 per cent increase in the total illegitimate birth rate of unmarried women aged 15 to 49 years, from 1931 to 1941 (Table 3).

The highest illegitimate birth rate in each census year is found in the 20-24 years age group until 1951 , but after that the $25-29$ years age group assumes the highest value. The drop in the average age at marriage in Canada has resulted in a higher number of married women in younger age groups. Consequently, the proportion of births being legitimized by marriage in younger age groups also increases. This is perhaps the reason for the observed change in the illegitimate birth rates of Canada. 
Raghubar D. Sharma

TABLE 1. ILLEGITIMATE BIRTHS, AS PERCENTAGE OF TOTAL LIVE BIRTHS CANADA: $1921-1972$

\begin{tabular}{|c|c|c|c|}
\hline Year & $\begin{array}{c}\text { Illegitimate } \\
\text { Births }\end{array}$ & Year & $\begin{array}{c}\text { I1legitimate } \\
\text { Births }\end{array}$ \\
\hline $\begin{array}{l}1921 \\
1922 \\
1923 \\
1924 \\
1925\end{array}$ & $\begin{array}{l}1.97^{2} \\
2.05^{3} \\
2.17^{3} \\
2.34^{3} \\
2.60^{3}\end{array}$ & $\begin{array}{l}1946 \\
1947 \\
1948 \\
1949 \\
1950\end{array}$ & $\begin{array}{l}4.1 \\
4.0 \\
4.3 \\
3.9 \\
3.9\end{array}$ \\
\hline $\begin{array}{l}1926 \\
1927 \\
1928 \\
1929 \\
1930\end{array}$ & $\begin{array}{l}2.63 \\
2.85 \\
3.06 \\
3.17 \\
3.30\end{array}$ & $\begin{array}{l}1951 \\
1952 \\
1953 \\
1954 \\
1955\end{array}$ & $\begin{array}{l}3.8 \\
3.8 \\
3.8 \\
3.9 \\
3.8\end{array}$ \\
\hline $\begin{array}{l}1931 \\
1932 \\
1933 \\
1934 \\
1935\end{array}$ & $\begin{array}{l}3.46 \\
3.57 \\
3.77 \\
3.65 \\
3.74\end{array}$ & $\begin{array}{l}1956 \\
1957 \\
1958 \\
1959 \\
1960\end{array}$ & $\begin{array}{l}3.9 \\
4.0 \\
4.0 \\
4.2 \\
4.3\end{array}$ \\
\hline $\begin{array}{l}1936 \\
1937 \\
1938 \\
1939 \\
1940\end{array}$ & $\begin{array}{l}3.9 \\
3.9 \\
4.0 \\
3.9 \\
3.9\end{array}$ & $\begin{array}{l}1961 \\
1962 \\
1963 \\
1964 \\
1965\end{array}$ & $\begin{array}{l}4.5 \\
4.8 \\
5.3 \\
5.9 \\
6.7\end{array}$ \\
\hline \multirow[t]{2}{*}{$\begin{array}{l}1941 \\
1942 \\
1943 \\
1944 \\
1945\end{array}$} & $\begin{array}{l}4.0 \\
4.1 \\
4.1 \\
4.2 \\
4.5\end{array}$ & $\begin{array}{l}1966 \\
1967 \\
1968 \\
1969 \\
1970\end{array}$ & $\begin{array}{l}7.6 \\
8.3 \\
9.0 \\
9.2 \\
9.6\end{array}$ \\
\hline & & $\begin{array}{l}1971 \\
1972\end{array}$ & $\begin{array}{l}9.0 \\
9.0\end{array}$ \\
\hline
\end{tabular}

1. Illegitimacy in this report does not refer to births conceived out of wedlock but those in which parents reported themselves as not having been married to each other at the time of birth or registration and, in the case on Ontario, since 1949, those in which the marital status of the mother was reported as "single".

2. Excluding Newfoundland and Quebec.

3. Excluding Quebec.

4. Since 1949 "illegitimate" in the case of Ontario includes births to mothers whose marital status was reported as "single".

SOURCE: Vital Statistics Report of Statistics Canada. 
FIGURE 1. ILLEGITIMATE BIRTHS, AS PERCENTAGE OF TOTAL BIRTHS FOR

CANADA, 1921-1972

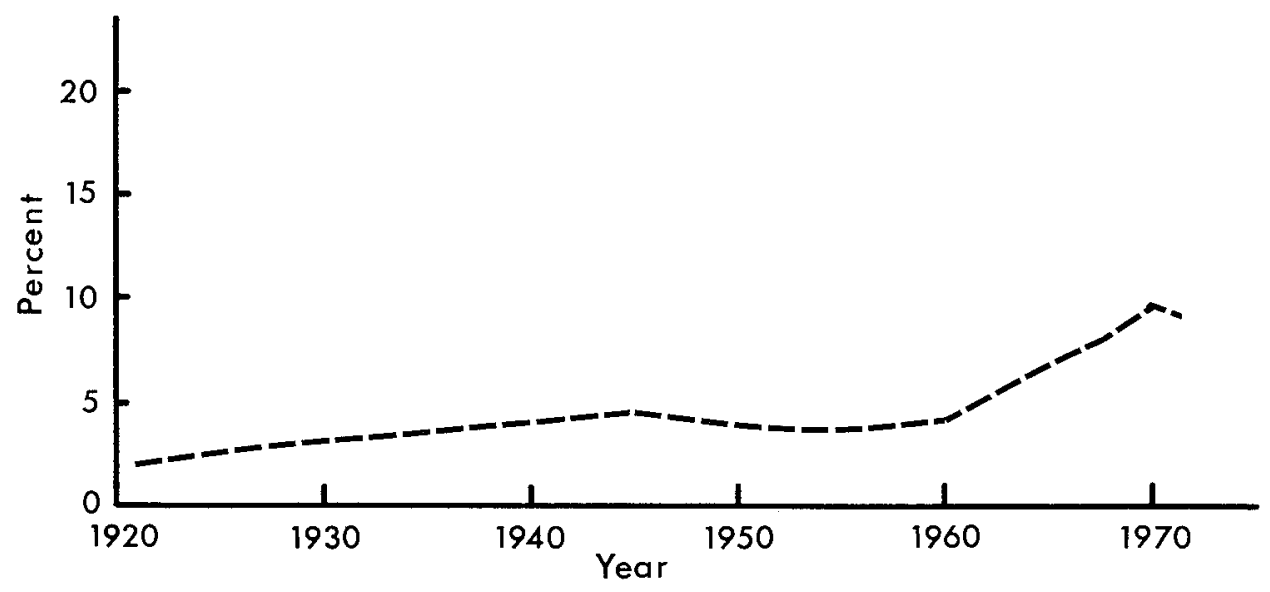

TABLE 2. AGE-SPECIFIC ILLEGITIMATE BIRTH RATE FOR CANADA, 1921-1971 (CENSUS YEARS)

\begin{tabular}{|c|c|c|c|c|c|c|c|c|}
\hline \multirow{2}{*}{ Year } & \multicolumn{8}{|c|}{ Age of Mother } \\
\hline & $15-19$ & $20-24$ & $25-29$ & $30-34$ & $35-39$ & $40-44$ & $45-49$ & $14-49$ \\
\hline 1921 & 4.9 & 8.5 & 6.0 & 5.5 & 4.1 & 1.4 & 0.2 & 5.5 \\
\hline 1931 & 4.7 & 13.0 & 10.9 & 7.8 & 5.5 & 2.5 & 0.4 & 7.4 \\
\hline 1941 & 5.8 & 12.7 & 10.9 & 7.3 & 5.4 & 2.1 & 0.3 & 7.7 \\
\hline 1951 & 9.1 & 19.9 & 19.6 & 13.8 & 7.9 & 2.6 & 0.3 & 12.4 \\
\hline 1956 & 11.1 & 23.9 & 26.3 & 19.8 & 11.9 & 3.6 & 0.3 & 14.7 \\
\hline 1961 & 12.7 & 20.7 & 31.6 & 23.2 & 13.1 & 4.2 & 0.2 & 16.7 \\
\hline 1966 & 14.4 & 31.5 & 37.6 & 27.3 & 15.2 & 4.9 & 0.3 & 18.9 \\
\hline 1971 & 15.2 & 25.5 & 27.0 & 21.8 & 11.6 & 3.4 & 0.2 & 17.4 \\
\hline
\end{tabular}

There is a rhythmic rise and fall in the illegitimate birth rate of the $45-49$ age group from 1921 to 1971 , and in the case of women of over 25 , rates decrease with the increase in the age of mother (Table 2). 
From 1966 to 1971, illegitimate birth rates fell for all age groups, except for the 15-19 years group. The illegitimate birth rate for all unmarried women (15-49) declined in 1971 by about 8.0 per cent as compared to 1966 . This overall decline could be due to a rise in the proportion of unmarried women, the change in the abortion laws of Canada, and the prevalent of use of contraceptives among younger unmarried women.

Table 3 reveals that the highest rise in the illegitimate birth rate (15-49) took place during the Depression period (from 1931 to 1941). This point is discussed in the next section.

TABLE 3. PERCENTAGE CHANGE IN ILLEGITIMATE BIRTH RATE (15-49) CANADA: 1921-1971 (CENSUS YEARS)

\begin{tabular}{lll}
\hline From & To & $\begin{array}{c}\text { Per Cent } \\
\text { Change }\end{array}$ \\
\hline 1921 & 1931 & +35.3 \\
1931 & 1941 & +3.9 \\
1941 & 1951 & +60.2 \\
1951 & 1956 & +18.7 \\
1956 & 1961 & +13.8 \\
1961 & 1966 & +13.0 \\
1966 & 1971 & -7.8 \\
\hline
\end{tabular}

\section{Trends in Age-Specific Illegitimate Birth Rates in the Post-World-War-II Years}

War has been one of the greatest causes of human mortality. The high mortality of young males influences sex ratio in a society, which in turn affects the phenomenon of reproduction and the social institutions surrounding it. World War II influenced economic conditions and migrations. During the war years, displacement of troops took place, and during the post-war years, a great number of international migrations occurred. These conditions of relatively-high male migration and high male mortality affected human fertility and more so illegitimacy.

Illegitimate fertility is probably not independent of nuptiality: an increase in nuptiality tends to decrease illegitimacy. The economic prosperity which accompanied and followed the last war brought a marked rise in nuptiality (Henripin, 1972). Moreover, numerous couples were separated until 1946, which can be an additional reason for high illegitimacy during these years.

Table 4 gives specific illegitimate birth rates from 1946 to 1972, and Table 5 gives per cent change in the illegitimate birth rate for all women of childbearing ages (15-49).

The baby boom of the 1940s continued through the 1950s and into the 1960s (Thomlinson, 1967:167). This boom is attributed to a larger number of women, more married women, more wives bearing children, and more total births per woman. Usually a rise in marital fertility in a society results in a fall in illegitimacy. Canada's marital fertility began to decline in 1958, but illegitimate birth rates continued to rise. This indicates a change in social attitudes towards premarital sex and illegitimacy. The illegitimate birth rate for all women (15-49) rose by 264.5 per cent from 1921 to 1946 and by 84.4 per cent from 1946 to 1970 . 
TABLE 4. AGE-SPECIFIC ILLEGITIMATE BIRTH RATES PER 1000 UNMARRIED WOMEN FOR CANADA, 1946-1972

\begin{tabular}{|c|c|c|c|c|c|c|c|c|}
\hline \multirow[t]{2}{*}{ Year } & \multicolumn{8}{|c|}{ Age of Mother } \\
\hline & $15-19$ & $20-24$ & $25-29$ & $30-34$ & $35-39$ & $40-44$ & $45-49$ & $15-49$ \\
\hline $\begin{array}{l}1946 \\
1947 \\
1948 \\
1949 \\
1950\end{array}$ & $\begin{array}{l}8.2 \\
8.9 \\
9.4 \\
9.3 \\
9.4\end{array}$ & $\begin{array}{l}19.2 \\
21.1 \\
21.7 \\
19.1 \\
19.0\end{array}$ & $\begin{array}{l}14.9 \\
18.9 \\
21.5 \\
18.3 \\
19.2\end{array}$ & $\begin{array}{l}10.0 \\
13.0 \\
13.9 \\
11.4 \\
11.1\end{array}$ & $\begin{array}{l}7.3 \\
8.3 \\
9.7 \\
6.7 \\
8.0\end{array}$ & $\begin{array}{l}2.6 \\
2.8 \\
2.9 \\
2.1 \\
2.4\end{array}$ & $\begin{array}{l}0.3 \\
0.3 \\
0.3 \\
0.3 \\
0.3\end{array}$ & $\begin{array}{l}10.9 \\
12.1 \\
11.4 \\
11.6 \\
12.6\end{array}$ \\
\hline $\begin{array}{l}1951 \\
1952 \\
1953 \\
1954 \\
1955\end{array}$ & $\begin{array}{r}9.9 \\
9.9 \\
10.3 \\
10.5 \\
10.2\end{array}$ & $\begin{array}{l}19.9 \\
21.1 \\
22.0 \\
23.4 \\
23.2\end{array}$ & $\begin{array}{l}19.5 \\
21.5 \\
22.3 \\
24.2 \\
24.7\end{array}$ & $\begin{array}{l}13.8 \\
14.4 \\
17.0 \\
18.2 \\
19.5\end{array}$ & $\begin{array}{r}7.9 \\
7.9 \\
8.5 \\
9.1 \\
10.1\end{array}$ & $\begin{array}{l}2.6 \\
3.1 \\
3.4 \\
3.5 \\
3.4\end{array}$ & $\begin{array}{l}0.3 \\
0.2 \\
0.2 \\
0.3 \\
0.2\end{array}$ & $\begin{array}{l}12.4 \\
12.6 \\
13.1 \\
13.8 \\
13.8\end{array}$ \\
\hline $\begin{array}{l}1956 \\
1957 \\
1958 \\
1959 \\
1960\end{array}$ & $\begin{array}{l}11.1 \\
11.9 \\
11.7 \\
12.5 \\
12.2\end{array}$ & $\begin{array}{l}23.9 \\
24.4 \\
25.6 \\
27.6 \\
27.6\end{array}$ & $\begin{array}{l}26.3 \\
24.6 \\
26.4 \\
27.2 \\
28.9\end{array}$ & $\begin{array}{l}19.8 \\
19.7 \\
21.5 \\
22.2 \\
21.6\end{array}$ & $\begin{array}{l}11.9 \\
12.0 \\
12.8 \\
14.5 \\
13.6\end{array}$ & $\begin{array}{l}3.6 \\
3.3 \\
3.5 \\
4.1 \\
3.7\end{array}$ & $\begin{array}{l}0.3 \\
0.5 \\
0.4 \\
0.3 \\
0.2\end{array}$ & $\begin{array}{l}14.7 \\
15.0 \\
15.4 \\
16.2 \\
15.9\end{array}$ \\
\hline $\begin{array}{l}1961 \\
1962 \\
1963 \\
1964 \\
1965\end{array}$ & $\begin{array}{l}12.7 \\
11.9 \\
12.6 \\
13.0 \\
13.3\end{array}$ & $\begin{array}{l}29.7 \\
30.4 \\
31.3 \\
32.0 \\
32.4\end{array}$ & $\begin{array}{l}31.6 \\
32.0 \\
31.8 \\
34.7 \\
35.2\end{array}$ & $\begin{array}{l}23.2 \\
24.5 \\
26.3 \\
28.1 \\
27.5\end{array}$ & $\begin{array}{l}13.1 \\
13.7 \\
14.4 \\
14.8 \\
15.3\end{array}$ & $\begin{array}{l}4.2 \\
4.4 \\
4.7 \\
5.6 \\
5.0\end{array}$ & $\begin{array}{l}0.2 \\
0.2 \\
0.2 \\
0.3 \\
0.3\end{array}$ & $\begin{array}{l}16.7 \\
16.2 \\
16.9 \\
17.7 \\
18.1\end{array}$ \\
\hline $\begin{array}{l}1966 \\
1967 \\
1968 \\
1969 \\
1970 \\
1971 \\
1972\end{array}$ & $\begin{array}{l}14.4 \\
14.0 \\
14.5 \\
15.1 \\
16.3 \\
15.2 \\
14.3\end{array}$ & $\begin{array}{l}31.5 \\
33.0 \\
34.4 \\
34.1 \\
31.9 \\
25.5 \\
21.8\end{array}$ & $\begin{array}{l}37.6 \\
35.3 \\
33.4 \\
30.5 \\
41.0 \\
27.0 \\
25.2\end{array}$ & $\begin{array}{l}27.3 \\
25.6 \\
27.1 \\
27.8 \\
27.5 \\
21.8 \\
20.9\end{array}$ & $\begin{array}{l}15.2 \\
15.1 \\
15.0 \\
15.4 \\
13.3 \\
11.6 \\
10.7\end{array}$ & $\begin{array}{l}4.9 \\
4.0 \\
4.1 \\
4.1 \\
3.1 \\
3.4 \\
3.4\end{array}$ & $\begin{array}{l}0.3 \\
0.3 \\
0.3 \\
0.4 \\
0.3 \\
0.2 \\
0.2\end{array}$ & $\begin{array}{l}18.9 \\
18.8 \\
19.3 \\
19.5 \\
20.1 \\
17.4 \\
16.7\end{array}$ \\
\hline
\end{tabular}

After a prolonged rise, age-specific illegitimate birth rates began to decline in 1971 . The percentage decline in the illegitimate birth rate for women of all ages (15-49) is about 13 from 1970 to 1971 and about 4 from 1971 to 1972 (Table 5). This decline in illegitimacy in the 1970s is usually attributed to amendments in the Criminal Code in 1969, which legalized therapeutic abortion under specific circumstances (Harding and Hunter, 1971; Morah, 1975). However it might also be attributable to the increasing use of contraceptives among unmarried women. 
TABLE 5. PERCENTAGE CHANGE IN ILLEGITIMATE BIRTH RATE (15-49) IN CANADA DURING POST-WORLD-WAR YEARS

\begin{tabular}{lll}
\hline From & To & $\begin{array}{c}\text { Per Cent } \\
\text { Change }\end{array}$ \\
\hline 1941 & 1946 & +41.0 \\
1946 & 1950 & +15.6 \\
1950 & 1955 & +9.5 \\
1955 & 1960 & +15.2 \\
1960 & 1965 & +13.8 \\
1965 & 1970 & +11.1 \\
1970 & 1971 & -13.4 \\
1971 & 1972 & -4.0 \\
& & \\
1921 & 1970 & +265.5 \\
1921 & 1972 & +203.6 \\
1946 & 1970 & +84.4 \\
1946 & 1972 & +53.2 \\
\hline
\end{tabular}

Abortions performed in Canada totalled 11,152 in 1970; 30,923 in 1971; and 38,853 in 1972, constituting to 3.0, 8.6, and 11.2 per cent of live births, respectively (Statistics Canada, Catalogue 82-211 Annual). According to Grindstaff (1975), nearly half the abortions in 1972 and 1973 were performed on women under the age of 21 , and usually unmarried. Our recent analysis showed an upward trend in illegitimacy among teenage mothers in most of the Canadian provinces (Sharma, 1976). While the number of unmarried women in higher age groups is always very low, the number of unmarried women under the age of 21 is usually very high. The therapeutic abortions performed on women under this age should naturally be higher. When the number of abortions in the teenage (15-19) group is related to the number of unmarried women in this age group, the abortion rate is very low (Sharma, 1976). This means that although the teenage group did not have a higher incidence of abortions per 1,000 women as compared to older age groups, a much larger absolute number of abortions was performed on teenage women. The influence of abortions on the decline of illegitimacy will require long-term study.

\section{International Comparison}

After obtaining a picture of age-specific illegitimate birth rates in Canada, it will be interesting to know how similar or different they are vis-à-vis other populations of the world. Unfortunately, there is a scarcity of information on illegitimate births in Asian and African countries; however, it is possible to find data on some European countries, Australia, and the U.S.A. An attempt will be made to examine the differences in illegitimacy between Canada, Australia, the U.S.A., and Denmark. 


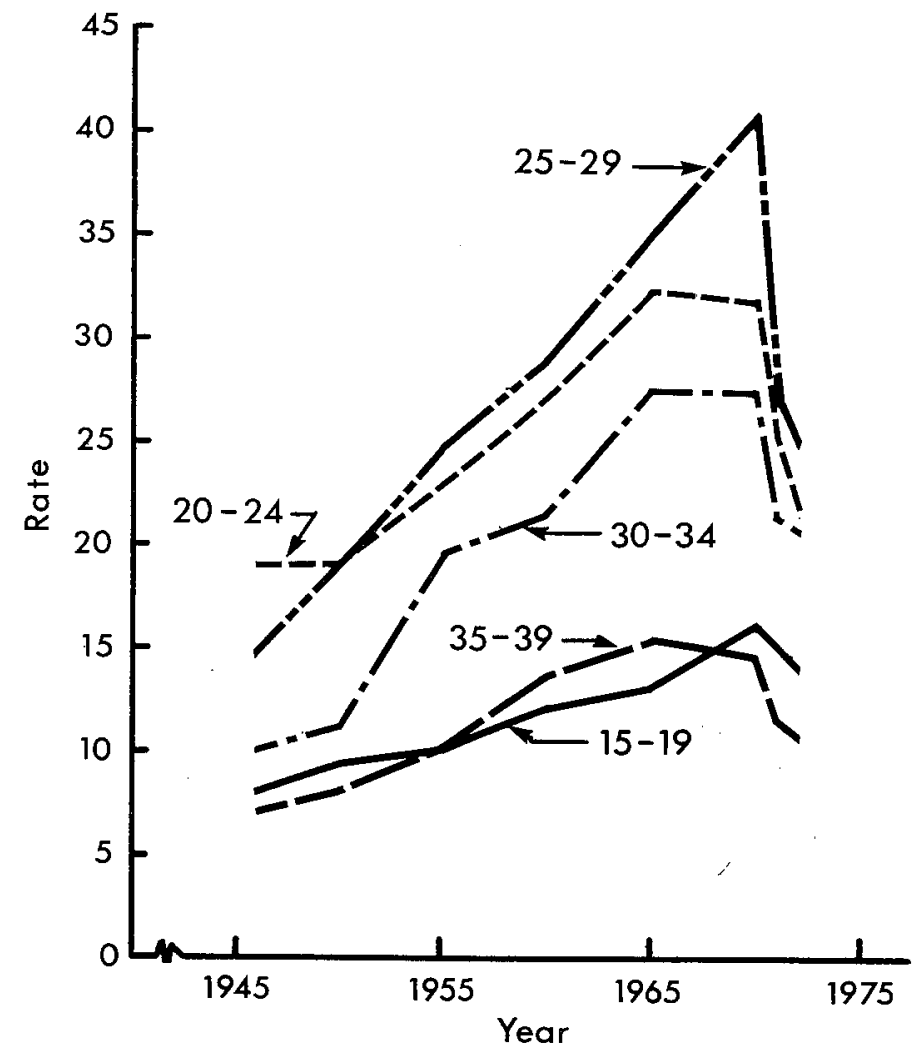

\section{Comparison Between Canada and Australia}

Table 6 compares age-specific illegitimate birth rates of Canada and Australia. It can be seen that in 1921, the rates for Australia were about double those for Canada in all age groups. By 1941, agespecific illegitimate fertility rates in Australia had dropped substantially, whereas Canadian rates showed a considerable increase. In 1941, Australian women under 30 had lower rates than their counterparts in Canada, whereas the rates for Australian women over 30 were higher. The illegitimate birth rate for all women (15-49) was lower for Australia than for Canada in 1941. In 1951, rates for Australia took a big leap in all age groups except 45-49. It is interesting to note that rates for women under 25 were higher in Canada than in Australia, whereas for all other women, they were higher in Australia. The total illegitimate fertility rate (15-49) remained about the same in both countries. 
Raghubar D. Sharma

TABLE 6. ILLEGITIMATE AGE-SPECIFIC FERTILITY RATES FOR CANADA AND AUSTRALIA

\begin{tabular}{|c|c|c|c|c|c|c|c|c|}
\hline \multirow{2}{*}{ Age Group } & \multicolumn{2}{|c|}{1921} & \multicolumn{2}{|c|}{1941} & \multicolumn{2}{|c|}{1951} & \multicolumn{2}{|c|}{1966} \\
\hline & Canada & Australia & Canada & Australia & Canada & Australia & Canada & Australia \\
\hline $15-19$ & 4.9 & 7.3 & 5.8 & 4.4 & 9.9 & 6.8 & 14.4 & 13.9 \\
\hline $20-24$ & 8.5 & 15.4 & 12.7 & 10.0 & 19.9 & 17.2 & 31.5 & 27.6 \\
\hline $25-29$ & 6.0 & 13.2 & 10.9 & 10.5 & 19.6 & 26.0 & 37.6 & 52.3 \\
\hline $30-34$ & 5.5 & 11.8 & 7.3 & 10.5 & 13.8 & 23.5 & 27.3 & 52.3 \\
\hline $35-39$ & 4.1 & 9.6 & 5.4 & 7.3 & 7.9 & 12.6 & 15.2 & 30.7 \\
\hline $40-44$ & 1.4 & 3.9 & 2.1 & 3.3 & 2.6 & 5.3 & 4.9 & 10.6 \\
\hline $45-49$ & 0.2 & 0.4 & 0.3 & 0.5 & 0.3 & 0.4 & 0.3 & 0.5 \\
\hline $15-49$ & 5.5 & 10.0 & 7.7 & 6.8 & 12.4 & 12.0 & 18.9 & 20.0 \\
\hline
\end{tabular}

NOTE: Figures for Australia have been collected from the Appendix of "Pre-Marital Pregnancies and Ex-nuptial Birth," by K.G. Basavarajappa.

The year 1966 gives an interesting comparative picture. The total illegitimate fertility rate (15-49) is about 19.0 for Canada and 20.0 for Australia. There are, however, marked differences between age-specific illegitimate birth rates in the two populations. In other words, there are differences in ex-nuptial and pre-marital coital behavior in the two countries with respect to age groups. In Australia, the rates are higher in older women and lower in younger (15-24) women. Australian rates are about double those in Canada for the 30-34 and 35-39 age groups.

\section{Comparison Between Canada and the United States of America}

It is evident from the Table 7 that, like Australia and Canada, there is an upward trend in illegitimacy in the U.S.A. from 1940 to 1965 . If we compare age-specific illegitimate birth rates for 1941 in Canada with those of 1940 in the U.S.A., it is clear that the higher figures are found in the 20-24 age group in both countries. For these years, the rate for teenage (15-19) women is lower in Canada than in U.S.A., while the opposite is true for women over 20 . The higher illegitimate birth rate of the teenage group (15-19) in the U.S.A. contributes to a higher illegitimate birth rate for all women of childbearing age (15-44).

Age-specific illegitimate birth rates for 1950 are lower in Canada than in the U.S.A. for all women under 35. Older women (35-44) in Canada have a slightly higher rate than their American counterparts. The illegitimate birth rate of all women (15-44) is higher in the U.S.A. For the years 1960 and 1965 , age-specific illegitimate birth rates for women below 35 are considerably lower in Canada than in U.S.A., while illegitimate birth rates for women over 35 are equal.

It has been reported in many studies that the illegitimate birth rate of the U.S.A. is inflated by the high illegitimacy rate of the black population. To test the validity of this notion, a comparison was made between the illegitimacy rates of whites in the U.S.A. and the total population of Canada.

Comparison Between Canada and the White Population of the U.S.A.

Table 8 depicts age-specific illegitimate fertility rates for Canada and the American white 
population. The differences between the two can be summarized in one sentence: The illegitimate birth rates of the white population of the U.S.A. are lower than those of Canada for all age groups in all given years from 1945 to 1968 , without exception. The similarity between the two is that both populations show upward trends.

\section{FIGURE 3. ILLEGITIMATE BIRTH RATE (15-49) FOR VARIOUS COUNTRIES}

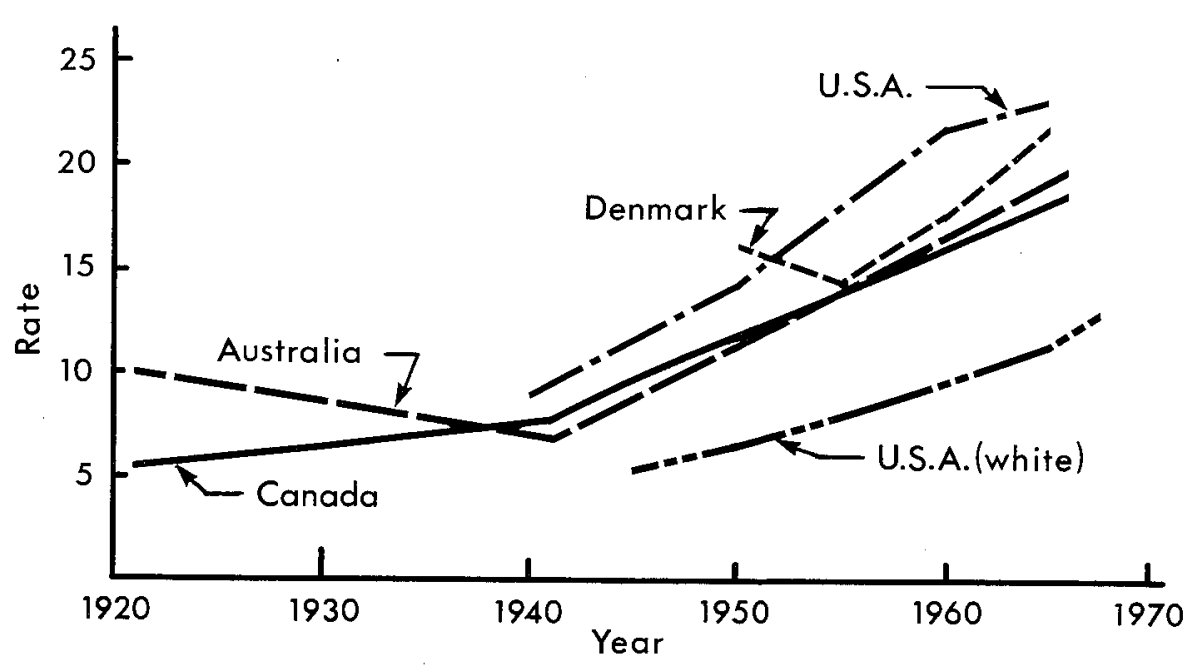

\section{Comparison Between Canada and Denmark}

One of the reasons for choosing Denmark as the European country for comparison is that the Scandinavian countries are stereotyped as having high levels of illegitimacy and pre-marital relations. Table 9 compares age-specific birth rates for Canada and Denmark from 1950 to 1965 at five year intervals. Except for a slight decline from 1950 to 1955 , rates for Denmark show a rise in most age groups in all given years. The illegitimate birth rate for total unmarried women of childbearing age (15-49) is higher for Denmark than for Canada in each given year, but differences are comparable to those between Canada and the United States.

In 1950, age-specific illegitimate birth rates are higher for Denmark for all age groups except 45-49, where we notice a higher rate in Canada. In 1955, the picture changes slightly: the rates are lower for women under 25 in Canada than in Denmark, but are higher for the 25-29, 30-34, and 40-44 age groups. Women of 35-39 have about the same rate in both countries; older women (45-49) have a slightly higher rate for Denmark than for Canada. Illegitimate births for total unmarried women of childbearing age (15-49) in Canada exceed those in Denmark by only about 1 per 1,000 . 
Raghubar D. Sharma

For 1960, Canadian unmarried women under 40 have lower rates, and women over 40 have higher rates, than those of Denmark. The illegitimate birth rate of Denmark for total unmarried women (15-49) exceeds that of Canada, because it is inflated by younger age groups in Denmark. For 1965, the illegitimate fertility rates of women under 30 are higher in Denmark than in Canada. The rates are about equal for the 30-34 age group. The illegitimate fertility rate of total unmarried women (15-49) is also higher for Denmark in 1965. The trend remains the same as in 1960.

TABLE 7. AGE-SPECIFIC ILLEGITIMATE FERTILITY RATES FOR CANADA AND U.S.A.

\begin{tabular}{|c|c|c|c|c|c|c|c|c|}
\hline \multirow{2}{*}{ Age Groups } & \multirow{2}{*}{$\frac{1941}{\text { Canada }}$} & \multirow{2}{*}{$\frac{1940}{\text { U.S.A. }}$} & \multicolumn{2}{|c|}{1950} & \multicolumn{2}{|c|}{1960} & \multicolumn{2}{|c|}{1965} \\
\hline & & & Canada & $\overline{\text { U.S.A. }}$ & Canada & U.S.A. & Canada & U.S.A. \\
\hline $15-19$ & 5.8 & 8.7 & 9.4 & 13.6 & 12.2 & 16.4 & 13.3 & 17.5 \\
\hline $20-24$ & 12.7 & 10.6 & 19.0 & 21.7 & 27.6 & 39.9 & 32.4 & 39.3 \\
\hline $25-29$ & 10.9 & 8.1 & 19.2 & 20.5 & 28.9 & 41.7 & 35.2 & 48.4 \\
\hline $30-34$ & 7.3 & 5.8 & 11.1 & 13.7 & 21.6 & 27.8 & 27.5 & 37.2 \\
\hline $35-441$ & 3.7 & 2.8 & 5.7 & 4.7 & 8.7 & 8.8 & 10.2 & 10.3 \\
\hline $15-44^{2}$ & 7.7 & 8.0 & 12.6 & 14.5 & 15.9 & 21.7 & 18.1 & 23.4 \\
\hline
\end{tabular}

1 For Canada it is average of illegitimate fertility rates of 35-39 and 40-44 age groups.

2 Total illegitimate fertility for Canada pertains to women 15-49, not 15-44.

SOURCE: Data for the U.S, have been collected from "Illegitimacy and U.S. General Fertility Growth," by $F$. Cutright and 0 . Galle, Pop. Studies, Vol. 27, No.3, 1973.

TABLE 8. AGE-SPECIFIC ILLEGITIMATE FERTILITY RATES FOR CANADA AND THE WHITE AMERICAN POPULATION

\begin{tabular}{|c|c|c|c|c|c|c|c|c|}
\hline \multirow[b]{2}{*}{ Age Groups } & \multirow{2}{*}{$\frac{1946}{\text { Canada }}$} & \multirow{2}{*}{$\frac{1945}{\begin{array}{c}\text { U.S.A. } \\
\text { (Whites) }\end{array}}$} & \multicolumn{2}{|c|}{1955} & \multicolumn{2}{|c|}{1965} & \multicolumn{2}{|c|}{1968} \\
\hline & & & Canada & $\begin{array}{l}\text { U.S.A. } \\
\text { (Whites) }\end{array}$ & Canada & $\begin{array}{c}\text { U.S.A. } \\
\text { (Whites) }\end{array}$ & Canada & $\begin{array}{c}\text { U.S.A. } \\
\text { (Whites) }\end{array}$ \\
\hline $15-19$ & 8.2 & 4.4 & 10.2 & 6.2 & 13.3 & 8.0 & 14.5 & 9.9 \\
\hline $20-24$ & 19.2 & 10.1 & 23.2 & 14.9 & 32.4 & 21.7 & 34.4 & 22.6 \\
\hline $25-29$ & 14.9 & 7.6 & 24.7 & 13.3 & 35.2 & 23.8 & 33.4 & 21.5 \\
\hline $30-34$ & 10.0 & 3.9 & 19.5 & 8.7 & 27.5 & 16.4 & 27.1 & 14.9 \\
\hline $35-44^{1}$ & 4.9 & 1.5 & 6.7 & 2.8 & 10.1 & 4.9 & 9.5 & 4.7 \\
\hline $15-44^{2}$ & 10.9 & 5.5 & 13.8 & 7.9 & 18.1 & 11.5 & 19.3 & 13.0 \\
\hline
\end{tabular}

For Footnotes see Table 7. 
TABLE 9. ILLEGITIMATE BIRTHS PER 1000 SINGLE WOMEN AGED 15-49 YEARS, BY AGE FOR DENMARK AND CANADA

\begin{tabular}{|c|c|c|c|c|c|c|c|c|}
\hline \multirow{2}{*}{ Age Group } & \multicolumn{2}{|c|}{1950} & \multicolumn{2}{|c|}{1955} & \multicolumn{2}{|c|}{1960} & \multicolumn{2}{|c|}{2965} \\
\hline & Canada & Denmark & Canada & Denmark & Canada & Denmark & Canada & Denmark \\
\hline $15-19$ & 9.4 & 15.4 & 10.2 & 13.4 & 12.2 & 15.7 & 13.3 & 18.4 \\
\hline $20-24$ & 19.0 & 27.3 & 23.8 & 25.4 & 27.6 & 28.1 & 32.4 & 35.2 \\
\hline $25-29$ & 19.2 & 22.8 & 24.7 & 22.6 & 28.9 & 31.5 & 35.2 & 39.6 \\
\hline $30-34$ & 11.1 & 16.6 & 19.5 & 16.5 & 21.6 & 22.4 & 27.5 & 27.0 \\
\hline $35-39$ & 8.0 & 10.9 & 10.1 & 10.5 & 13.6 & 11.5 & 15.3 & 13.6 \\
\hline $40-44$ & 2.4 & 3.2 & 3.4 & 2.8 & 3.7 & 3.3 & 5.0 & 3.6 \\
\hline $45-49$ & 0.3 & 0.2 & 0.2 & 0.3 & 0.2 & 0.1 & 0.3 & 0.3 \\
\hline $15-49$ & 12.6 & 16.2 & 13.8 & 14.9 & 15.9 & 17.8 & 18.1 & 21.7 \\
\hline
\end{tabular}

NOTE: Source for Denmark figures is Statistical Department, Copenhagen.

From Premarital Pregnancies and Out-of-Wedlock births $1950-65$ by 5 . Goldstein. Population Studies, Vol. 4, No. 3, pp.925-937.

\section{Summary and Conclusions}

The present study deals with Canadian illegitimacy from 1921 to 1972 . Trends in illegitimacy have been examined on the basis of absolute numbers of illegitimate births, illegitimacy ratio, and agespecific illegitimacy rates. Changes in these rates have been discussed in terms of percentage change. Data for this study were collected from various government statistical reports.

The results indicate that, from 1921 to 1970 , there is an upward trend in all three measures of illegitimacy. After 1970, an abrupt decline in the number of illegitimate births, as well as in the illegitimate birth rate (15-49), is visible. This decline is usually attributed to the prevalence of therapeutic abortions after the change in the Canadian abortion law in 1969 , but our recent analysis shows that determining the effect of this change in abortion law on illegitimacy will require long-term study (Sharma, 1976).

An international comparison shows that the Canadian illegitimate birth rate (15-49) was substantially lower than that of Australia in 1921, about the same in 1941 and 1951, and slightly lower in 1966. The illegitimate birth rate (15-49) for Canada does not differ a great deal from that of the U.S.A. for 1940 and 1950, but it is much lower for 1960 and 1965. Mlegitimate birth rates of Canada are higher than those of the white population of U.S.A.; however, the American rates for the total population are higher, due to the high level of illegitimacy in the black population. The illegitimate fertility rate of all women (15-49) of Denmark exceeds that of Canada for all ages, but differences are not as marked as one would anticipate.

The rise in illegitimacy until 1970, in spite of the availability of a large variety of more reliable contraceptives, suggests that illegitimacy and sexual relations out of wedlock are becoming more permissive. Thus, a periodic study of attitudes toward pre-marital and ex-nuptial relations would be of further interest. The effect of illegitimacy on family structure of mothers and their social, psychological, and economic problems could be further analyzed with the help of sample surveys. 


\section{Acknowledgments}

This paper is a part of my Masters research. I am thankful to Dr. K.G. Basavarajappa for his supervision and to Dr. T.R. Balakrishnan for reading the manuscript of the study. Thanks are due to Mr. D. Palel for the editorial work and to anonymous referees for their suggestions.

\section{Footnotes}

1 Data for unmarried women by age were collected from the Census of Canada reports, volume 1, parts 3 to 5, for 1921, 1931 , 1941, 1946, 1951, 1961, 1966, and 1971. For 1972 and other inter-census years, Basavarajappa (1974) provided the estimated number of married women. The number of married women were excluded from total women to obtain the number of unmarried women. For 1941, women who were permanently separated for domestic reasons were also included among unmarried women.

2 The total illegitimate births of Canada exclude Newfoundland, Quebec, the Yukon and the Northwest Territories, for 1921, and the Northwest Territories for 1931 and 1941; therefore, for these years, unmarried women were also excluded from the denominator.

\section{References}

Basavarajappa, K.G. 1968. Pre-marital Pregnancies and Ex-nuptial Births in Australia, 1911-1966. Australian New Zealand Journal of Sociology 4(2):126-145.

1974. Trends in Fertility in Australia (Some Aspects in the Movements in Nuptial and Ex-nuptial Fertility During 1911-1971). Mimeograph.

Berkov, B. 1968. Illegitimate Births in California. Milbank Memorial Fund Quarterly 46:473-506.

Cutright, P. 1972. Illegitimacy in the United States: 1920-1968. Demographic and Social Aspects of Population Growth Research Reports. 1:377-438.

1973. Illegitimacy and Income Supplements. Studies in Public Welfare. Washington: U.S. Government Printing Office.

and O. Galle. 1973. Illegitimacy and U.S. General Fertility. Population Studies 27(3):515-526.

Goldstein, S. 1967. Pre-marital Pregnancies and Out of Wedlock Births 1950-1965. Population Studies 4(3):925-937.

Goode, W.J. 1966. Family Organization. In R.K. Merton and R.A. Nisbet (eds.), Contemporary Social Problems. New York: Harcourt, Brace and World.

Grindstaff, C.F. 1975. The Baby Bust: Change in Fertility Patterns in Canada. Canadian Studies in Population 2:15-21.

Harding, D. and A.J. Hunter. 1971. Abortion Techniques and Services: A Review Critique. American Journal of Public Health 61:2085.

Henripin, J. 1972. Trends and Factors of Fertility in Canada. Ottawa: Census Canada.

Kammerer, P.G. 1969. The Unmarried Mothers. New Jersey: Monclair.

Kumar, J. 1969. Demographic Analysis of Data on Illegitimate Births. Social Biology 16(2):92-108.

Laslett, P.O. and K. Oosterveen. 1973. Long Term Trends in Bastardy in England. Population Studies 27(2):255-286.

Morah, B. 1975. The Demographic Consequences of Liberalized Abortion Law in Canada. A paper presented to the Canadian Population Society Meetings at Quebec City, Quebec, Canada.

Sharma, R.D. 1976. Provincial Differentials in Pre-marital and Ex-nuptial Fertility in Canada. A paper presented to the Canadian Population Society Meetings at Quebec City, Quebec, Canada.

Span, C. 1912. Quoted in P.G. Kammerer. Unmarried Mothers. New Jersey: Monclair. 
Pre-Marital and Ex-Nuptial Fertility in Canada

State of California. 1967. Population Report to Governor. Berkeley, California: Department of Public Health. Thomlinson, R. 1965. Population Dynamics. New York: Random House.

Vincent, C.E. 1969. Unmarried Mothers, New York: Free Press.

Received July, 1975; revised February, 1980. 
